\title{
高温純水中における腐食電位測定の 誤差低減方法に関する検討
}

\author{
橘 正彦 $^{1) *}$ \\ 1）株式会社日立製作所研究開発グループエネルギーイノベーションセンタ
}

Investigation of Error Reduction Methods for Electrochemical Corrosion Potential Measurement in High Temperature-High Purity Water

\author{
Masahiko Tachibana ${ }^{1) *}$ \\ 1) Hitachi, Ltd., Research \& Development Group, Center for Technology Innovation - Energy
}

*責任著者(Corresponding Author) ＝319-1221 日立市大みか町 7-2-1(7-2-1 Omika-cho, Hitachi, 319-1221, Japan) E-mail: masahiko.tachibana.kh@hitachi.com

\begin{abstract}
The supersensitive measurement method for general electric circuit was applied to the ECP measurement method in high temperature water which simulated BWR temperature condition. Some issues which concerned with the measurement were clarified. Additionally, the countermeasures were divided to reduce measurement errors.

Key words : electrochemical corrosion potential, boiling water reactor, high temperature water, high purity water
\end{abstract}

1. 緒言

沸騰水型原子力発電プラント $(\mathrm{BWR})$ において, 構造材 や配管などの応力腐食割れ $(\mathrm{SCC})^{1)}$ を抑制することは, 安全性や経済性に関わる重要課題である.SCC を抑制す るために, 水質管理の観点では, 水素注入, 貴金属注入 などの予防保全技術などが行われている。それら予防保 全技術の効果の指標の一つとして, 腐食電位 $(\mathrm{ECP})$ が用 いられる. SCC の保護電位として, $-0.23 \mathrm{~V} v$ s. 標準水素 電極 $(\mathrm{SHE})^{2)}$ が知られている。水質管理により ECP を低 下させることで SCC を抑制できることから，日本機械 学会の発電用原子力設備規格 維持規格 (JSME S NA1) ${ }^{3)}$ においては, ECPを指標の一つとして SCC の進展速度 (CGR) を評価する考え方が記載されている.

BWR は電気伝導率の低い, すなわち抵抗率の高い純 水を冷却材として使用しており，かつ高温高圧環境であ る。このため, ECPを高い再現性で測定するためには適 切に測定系を構築する必要がある. BWRの定格運転中 における冷却材温度 $\left(\sim 288{ }^{\circ} \mathrm{C}\right)$ を模擬した純水中で測定 された ECPには, 報告者ごとにばらつきが認められる. 実験室系で測定された, BWRの定格運転中における冷 却材温度を模擬した条件における ECP の溶存酸素濃度 依存性 ${ }^{4)-8)}$ の測定例を Fig. 1 に示す. ECP は, 酸素濃度 に対して S 字型に変化し, 酸素濃度が数 10〜100 ppb の領域において, 酸素濃度変化に対して急激に変化す る. 酸素濃度 $1 \sim 5 \mathrm{ppb}$ の低濃度領域における ECP の差 異は $0.05 \mathrm{~V}$ 程度と比較的小さい。一方, 約 $10 \mathrm{ppb}$ 以上の 領域では報告者によって $0.1 \mathrm{~V}$ 以上の差異が生じている. 10〜100 ppb で ECP が大きく変化する領域は, 試験装置 内壁表面における酸素の還元反応に起因した，電極装荷 位置での酸素濃度制御性の低下や，電極表面の酸化皮膜

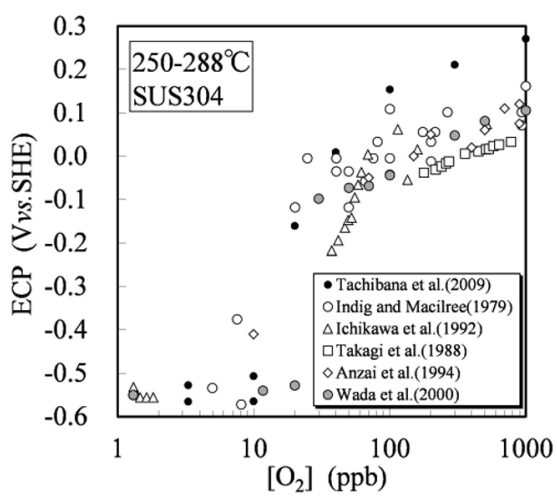

Fig. 1 Measured ECPs examples in Lab.

の成長度合いなどの影響を受けやすいため本質的にばら つきが大きくなる，一方，酸素の還元反応のカソード分 極曲線が，アノード分極曲線の過不働態域で交差するよ うになる $100 \mathrm{ppb}$ 以上の高濃度域 ${ }^{8)}$ では，前述の影響を 比較的受けにくくなることが考えられる. しかし Fig. 1 では, $100 \mathrm{ppb}$ 以上の高濃度域においても報告者によっ て $0.1 \mathrm{~V}$ 以上の差異が生じている.これら差違の要因は, 測定系や被測定系の設定条件の差違に起因した, 測定誤 差と実験誤差によるものと考える。差違が生じた理由 は, 試験水の流動条件や, 高温水中の試験片周囲での酸 素濃度などの, 報告書に明記されない要因による実験誤 差が，実験者によって異なる可能性があることに加え， 測定誤差が重畳した可能性がある。

SCC 進展速度評価はプラントの安全性に関係するた め, 測定される ECP の誤差を低減する必要があると考 える. 装置の仕様や実験目的に応じた条件の差違に起因 する実験誤差は不可避である。しかし測定系・被測定系 における電気的要因による測定誤差は極力低減すべきで 
ある. 前述した維持規格 ${ }^{3}$ では, 応力拡大係数と SCC 進 展速度との相関 (SCC 進展速度線図) が示されている.こ の SCC 進展速度線図は, 材料の違いと環境の違いに応 じて複数の線図が示されている. BWRの炉内構造材料 として広く用いられている SUS316L 鋼の SCC 進展速度 線図は, 通常炉内環境と, 水素注入環境の 2 種の線図が 示されており, 前者より後者のほうが低いSCC 進展速度 となっている。通常炉内環境と水素注入環境は ECP の範 囲で区別されており，前者は $\mathrm{ECP} \geqq 150 \mathrm{mVvs}$. SHE，後 者は $\mathrm{ECP} \leqq-100 \mathrm{mVvs}$. SHE とされている．両者の中間

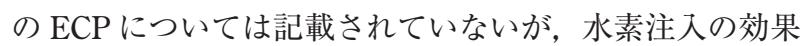
が得られているか否かを ECPによって確認するために, -100 mVvs. SHE を下回っているか否かの判定が重要とな る.しかしながら， $50 \mathrm{mV}$ 刻みで規定された值であるの か, $10 \mathrm{mV}$ 刻みで規定された值であるのかが不明であり, 要求精度が不明瞭である. ECP 評価に求められる精度は 不明瞭であるが，仮に $50 \mathrm{mV}$ 刻みで規定されたとした場 合， $-50 \mathrm{mVvs.} \mathrm{SHEであるか,}-100 \mathrm{mVvs.} \mathrm{SHEである}$

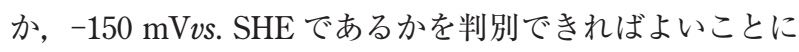
なる，このため，CGR 評価の一因子として ECP を評価す る際に要求される ECP の誤差(測定誤差+実験誤差) は小 さいほどよいことは言うまでもないが, 少なくとも $50 \mathrm{mV}$ 以下とすることが望ましいと考える.

一般に，ECP 測定は 2 極間の電位差を測定するのみで あるため，単純な系で測定可能である．常温常圧の抵抗 率が低い水溶液中で ECP 測定するための装置構成を Fig. 2 に示す. ECPは，基本的には電極間に電位差計を 接続するのみで測定できる。評価対象材料で製作した作 用電極 $(\mathrm{WE})$ と, 溶液相に対して一定の電位を有する参 照電極 $(\mathrm{RE})$ を装荷する， RE と WE との間に電位差計を 接続して，その電位差を測定する。通常，どの種類の参 照電極に対して測定した電位かを表示するか，または実 験温度における SHE を基準とした電位に換算して表示 する。

SHE を基準とした電位への換算方法の模式眓を Fig. 3 に示す. $\mathrm{RE}$ に対する WEの電位差 $\Delta E_{\text {meas }}$ が測定される ため, 式(1)で算出される。

$\mathrm{ECP}=\Delta E_{\text {meas }}+E_{\mathrm{RE}}$ ここで， $E_{\mathrm{RE}}$ は $\mathrm{SHE}$ を基準とした $\mathrm{RE}$ の電位であり， $\mathrm{RE}$ の種類や温度に依存した理論電位を用いる。このように, 抵抗率が低い水溶液中での ECP 測定は, 比較的容易に 測定できる.

しかしながら，前述したようにBWRの冷却材は純水

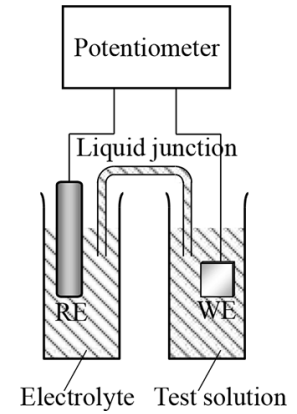

Fig. 2 Schematic view of ECP measurement apparatus for room temperature condition.
であり，液抵抗が高い点，および接地された金属容器内 での測定となる点などで常温常圧での ECP 測定とは異 なる $(2$ 章で後述する)。このため 3.1 節で後述するよう に, BWR 炉内温度を模擬した高温高圧純水中における ECP 測定では，被測定系に応じた測定系を構築する必要 がある。

電位測定では電位差計の入力インピーダンスの大きさ

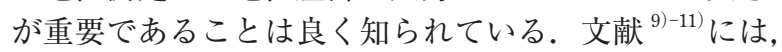
測定回路内に電流を流さない(電極を分極させない) とい う観点から, 推奨される電位差計の入力インピーダンス や, 許容される電流值の目安が示されている. 文献 ${ }^{12)} に$ は, 必要とされる電位差計の入力インピーダンスの算出 法が記載されている。文献 ${ }^{13)} に は$, 被測定系の抵抗の 100 倍以上の入力インピーダンスとすることが望ましい と述べられている。また, JAEA-Review 2012-007 ${ }^{14)} に$ は，軽水炉環境を対象とした高温水中での ECP 測定の 概要が述べられている. しかし, 高温高圧純水中を対象 とした，ECP 測定系の詳細構成を述べた文献は少ない。

同様に, 高温高圧純水中における ECP 測定法の規格・ 基準・ガイドラインは存在しない. 電位測定に係る規格 を Table1にまとめた. ATSM G215-16 ${ }^{15)} に は$ 電極電位測 定についての規定がある. ASTM G3-14 ${ }^{16)}$ ，および ISO

$17475: 2005^{17)}$ には, 腐食試験における電気化学測定 についての規定がある。ただしいずれも，高温高圧純水 中での測定には触れられていない。一方，JIS B 8224 附 属書 $\mathrm{D}^{18)}$ には，ボイラーを対象とした，高温水溶液中に おける ECP，および酸化還元電位の測定方法が示されて いる。しかし，高温高圧純水中を対象とした ECP 測定 方法の規格・基準・ガイドラインは存在しない.

高温高圧純水中を対象とした場合の標準的な測定方法 が規定されていないことも，報告者ごとに ECPがばら つく一因となっているものと考える．ECPのばらつきを

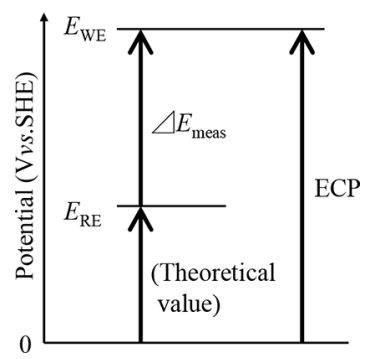

Fig. 3 Compensation method from raw potential to ECP base on SHE scale.

Table 1 Current codes and standards.

\begin{tabular}{|c|c|c|}
\hline $\begin{array}{c}\text { Standardizing } \\
\text { organizations }\end{array}$ & $\begin{array}{c}\text { Item } \\
\text { codes }\end{array}$ & Appellations \\
\hline $\begin{array}{c}\text { American Society } \\
\text { for Testing and } \\
\text { Materials }\end{array}$ & $\begin{array}{c}\text { ASTM } \\
\text { G215-16 }\end{array}$ & $\begin{array}{c}\text { Standard Guide for Electrode } \\
\text { Potential Measurement }\end{array}$ \\
\cline { 2 - 3 } & $\begin{array}{c}\text { G3-14 } \\
\text { Standard Practice for Conventions } \\
\text { Applicable to Electrochemical } \\
\text { Measurements in Corrosion } \\
\text { Testing }\end{array}$ \\
\hline $\begin{array}{c}\text { International } \\
\text { Organization for } \\
\text { Standardization }\end{array}$ & $\begin{array}{c}\text { ISO } \\
17475\end{array}$ & $\begin{array}{c}\text { Conventions applicable to } \\
\text { electrochemical measurements in } \\
\text { corrosion testing }\end{array}$ \\
\hline $\begin{array}{c}\text { Japan Standards } \\
\text { Association }\end{array}$ & JIS 8224 & $\begin{array}{c}\text { Boiler feed water and boiler } \\
\text { water-Testing methods } \\
\text { (Appendix D) }\end{array}$ \\
\hline
\end{tabular}


低減するためには，同一条件にできるところは極力同一 条件として測定し, かつ低減可能な誤差は極力低減して 測定することが必要と考える，本報では，主として測定 者が制御可能な測定系の構成に着目して, 電気的要因に よる ECP の測定誤差を低減可能な方法を検討した。

一般の電気回路を対象とした, 電気的要因による誤差 の低減方法は, 米国 Keithley 社により高感度測定ハンド ブック ${ }^{19)}$ としてまとめられている，本報では, 高感度測 定ハンドブック ${ }^{19)}$ に記載された誤差低隇方法を，高温高 圧純水中の ECP 測定に適用して, 測定誤差を低隇可能 な方法を検討した。次章で実験室系，ならびに実機にお ける代表的な ECP 測定方法の概要を述べ，3 章で被測定 系と測定系によって構成される電気回路を対象とした誤 差要因と課題を整理する。 4 章では, 各課題に対して, 高抵抗信号源からの電圧測定法 ${ }^{19)}$ ，ならびにエレクトロ メー夕の一般的注意事項 ${ }^{19}$ を高温高圧純水中の ECP 測 定に適用し，各誤差要因に対する対策法を述べる.

\section{2. 高温水中 ECP 測定の概要}

\section{1 実験室系における ECP 測定の概要}

実験室系で高温高圧水中の ECP 測定するための装 置の概要を Fig. 4 に示す。電極, 容器, 溶液, 電位差 計，記録計からなり，室温系での測定と同様の構成であ る. なお，本報では，BWRの定格運転中に扔ける原子 炉抢よび主要系統内の冷却材温度範囲 (約 $200 \sim 288^{\circ} \mathrm{C}$ ) の, 飽和蒸気圧以上に過圧された純水を高温高圧水と呼 称する.

高温高圧水環境を形成させるために，オートクレーブ と呼ばれる, 容量 $0.5 \sim 10 \mathrm{dm}^{3}$ 程度の金属製の容器を使 用する，オートクレーブは，外周部にヒーターを設置し て加熱して使用するため, 安全上の理由から接地して使 用されることが多い. BWR の炉内模擬温度で測定する 場合は, 純水を試験液として用いる。溶存酸素濃度など の水質を制御して測定する場合は，オートクレーブに循 環装置を接続して試験液を通水させる。オートクレーブ 内に, 評価対象材料で製作した WE と, 溶液相に対して 一定の電位を有する REを装荷する，高温で用いる $\mathrm{RE}$ には, 内部参照電極と外部参照電極がある， RE と WE

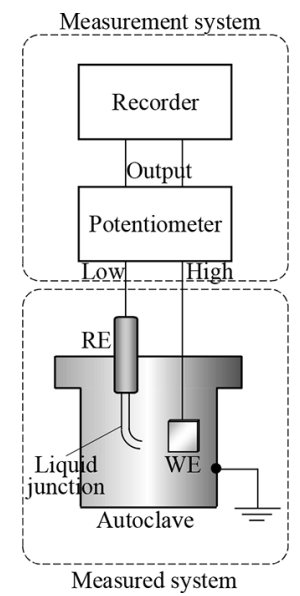

Fig. 4 Schematic view of ECP measurement apparatus for high temperature-high pressure condition.
との間に電位差計を接続して, その電位差を測定し, 記 録計などに出力して記録する.

通常, 測定した参照電極に対する電位を表示するか, または，実験温度におけるSHEを基準とした電位に換 算して表示する. SHE 基準の電位への換算は, Fig. 3 に 示した常温常圧系と同様の方法で, 式(1)を用いて換算 する.

実験室系に打ける，BWR 炉内温度の泠却材を模擬し た環境中における ECP 測定は, 溶液に抵抗率の高い純 水を使用する点, および接地容器内で測定する点に特徵 がある.

\section{2 実プラントにおける ECP 測定の概要}

BWR プラントの ECP 測定の一例として, 接地された 配管の ECP を直接測定する際 ${ }^{20)}$ の特徵を以下に述べる.

Fig. 5 に，接地された配管類を対象とした ECP 測定装置 の概要を示す。評価対象配管に, 同種材料で製作した T 字管やフランジなどの電極装荷用の配管部材を設けて参 照電極を装荷する．BWR プラントにおける ECP 測定で は, 内部参照電極 (ECP センサ)を使用することが多い. 原子力発電プラントの ECP 測定では，(1) 測定值の確度 を高めるため, (2) ECP センサ機能喪失時のバックアッ プのため, (3) 特定の温度や水質下でしか機能しない ECP センサがあるため, などの理由から複数本が装荷さ れる。たとえば銀/塩化銀型内部参照電極やジルコニア 隔膜型 ECP センサと, Pt 型 ECP センサなどのように, 複数種類の ECP センサを, 近接した位置に装荷するこ とが行われている ${ }^{20)}$.

この ECPセンサを装荷した電極装荷用の配管部材を, 評価対象部位に接続し，冷却材を導いて測定する。電極 装荷用の配管部材の外面には, 配管の電位をエレクトロ メータに伝達するためにクランプを取り付ける。このク ランプは, 熱澎張率の差による接触不良を避けるため, および熱起電力の発生を抑制するために, 電極装荷用の 配管部材と同種材料で製作される。これにより，クラン プを取付けた配管内の接水面を，電極として用いる．以 下，このクランプを取付けた部位の配管を「基本極」と 呼称する. この基本極を Low 端子に接続し，各 ECP セ ンサをHigh 端子に接続して, その電位差, つまり各 $\mathrm{ECP}$ センサの基本極に対する電位 $\Delta E_{\text {meas }}$ を測定，記録

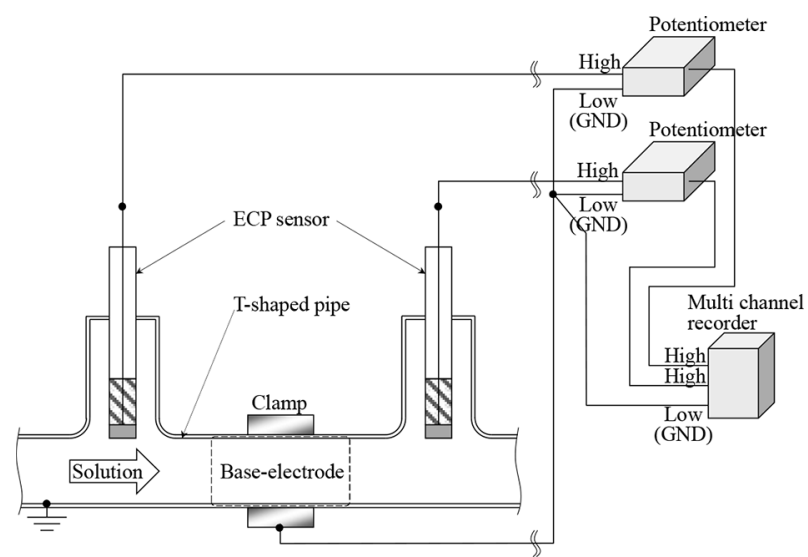

Fig. 5 The ECP measurement system for grounded piping. 


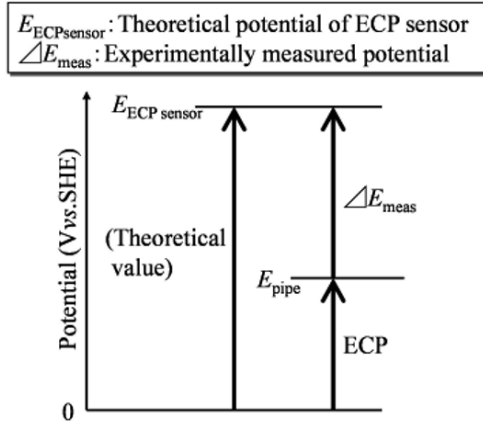

Fig. 6 Compensation method for raw potential which measured on an actual plant onto SHE scale.

する.このように，実機での ECP 測定では，Fig. 2 に示 した測定とは異なり，符号を反転させて測定する。そ的 理由は，接地レベルに対するインピーダンスが低い電極 をLow 端子に接続して測定するためであり, 詳細は 3 ・ 4 章で述べる. したがって $\Delta E_{\text {meas }}$ は, Fig. 6 に示す手法 で，SHEを基準とした ECP に補正して表示する。測 定・記録されるのは，基本極の電位 $E_{\text {pipe }}$ を基準とした $\mathrm{ECP}$ センサの電位 $E_{\mathrm{ECPsensor}}$ との電位差 $\Delta E_{\text {meas }}$ であるた め, 式(1)'に示すように $\Delta E_{\text {meas }}$ の符号を反転して, SHE 基準の $\mathrm{ECP}$ として求める.

$$
\mathrm{ECP}=-\Delta E_{\text {meas }}+E_{\mathrm{ECPsensor}}
$$

以上述べたように，BWR プラントにおける高温高圧 水中での ECP 測定は, 溶液が純水である点, および作 用極を設置せずに，ECP センサを使用して接地された T 字管などの電位を直接測定する点に特徵がある.

\section{3. 高温水中 ECP 測定の誤差要因}

高温高圧純水中での ECP 測定において，測定系，お よび被測定系に関係する誤差要因を Table 2 にまとめ た，誤差要因は，主として高抵抗溶液であることと，接 地容器内での測定であることに関係している，以下に個 別に述べる.

なお，以下では特に断りがない限り，測定誤差を単に 誤差と記載する。

Table 2 Error causes of ECP measurement in high temperaturehigh purity water.

\begin{tabular}{|c|l|}
\hline$\#$ & \multicolumn{1}{|c|}{ Causes of error } \\
\hline 1 & High impedance of the object to be measured. \\
\hline 2 & Noise overlapping caused by wiring connection method. \\
\hline 3 & Potential drift caused by measurement in grounded vessel. \\
\hline 4 & $\begin{array}{l}\text { Cable characteristics such as insulation resistance and electrostatic } \\
\text { capacity coupling. }\end{array}$ \\
\hline 5 & Grounding method. \\
\hline
\end{tabular}

\section{1 被測定系の抵抗に起因する誤差}

第 1 の要因は, 被測定系の抵抗の大きさに起因する電 位測定誤差である。簡素化した ECP 測定系の概要を Fig. 7 に示す。電位ソース $E_{\mathrm{S}}$ が ECP の発生源を表して

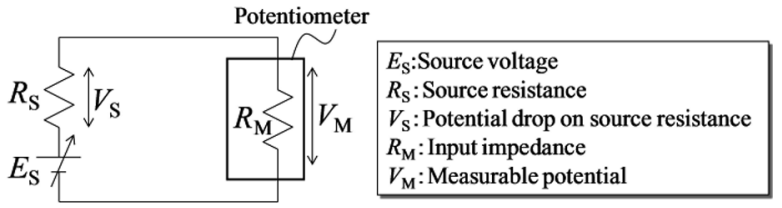

Fig. 7 Equivalent circuit of ECP measurement system.

おり，ソース抵抗 $R_{\mathrm{S}}$ が被測定系に含まれる液抵抗，電 荷移動抵抗，参照電極の膜抵抗などを含む全抵抗值を表 している. 入力インピーダンス $R_{\mathrm{M}}$ は電位差計の内部抵 抗である。

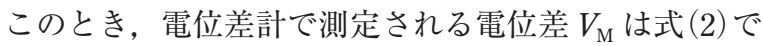
表され, $E_{\mathrm{S}}$ のうち $R_{\mathrm{M}}$ に分圧された分のみが測定される.

$$
V_{\mathrm{M}}=E_{\mathrm{S}} \frac{R_{\mathrm{M}}}{R_{\mathrm{S}}+R_{\mathrm{M}}}
$$

BWR 炉内模擬環境中における ECP 測定では，溶液が 純水であるため $R_{\mathrm{S}}$ が大きく，分圧による誤差が無視で きない大きさになる可能性がある.

超純水は電解質が $\mathrm{H}^{+}$と $\mathrm{OH}^{-}$のみであり, 常温で 18.2 $\mathrm{M} \Omega \cdot \mathrm{cm}$ の抵抗率を持つ絶縁体である．原子炉内を模擬 した温度域では, 後述するように水の解離定数が大きく なるため, 抵抗率は $1 \mathrm{M} \Omega \cdot \mathrm{cm}$ 程度に低下する。しか し, 電極や液絡の形状や寸法, 配置によっては高抵抗の 被測定系となる。実験室系の高温高圧水中の ECP 測定 で広く用いられる, 圧力平衡型外部参照電極 ${ }^{21)-23)}$ を使 用した場合には，液絡管を用いて試料表面近傍の電位を 検知する必要がある ${ }^{12)}$ 。高温水中では塩橋が使用できな いため, 液絡管内に試験液を満たして使用せざるを得な い. この場合, 液絡管内の純水が電気回路の経路となる ため，単純に電極を相対させた場合よりもさらに高液抵 抗となる.このため, ソース抵抗 $R_{\mathrm{S}}$ に比べて入力イン ピーダンス $R_{\mathrm{M}}$ が小さい電位差計を用いた場合に, 指示 值が真值からずれる. $R_{\mathrm{S}} \ll R_{\mathrm{M}}$ のときは $V_{\mathrm{M}}=E_{\mathrm{S}}$ となり 真值が測定される。一方, $R_{\mathrm{S}} \geqq R_{\mathrm{M}}$ である場合は式 (2) に従って分圧による誤差が生じ， $R_{\mathrm{S}} / R_{\mathrm{M}}$ の比に応じて $V_{\mathrm{M}}<E_{\mathrm{S}}$ なる $V_{\mathrm{M}}$ が計測される。

さらに，入力インピーダンスが低い電位差計を使用し た場合, 回路内に電流が流れることで電極が分極し, 正 しい電位を指示しなくなることが知られている．分極に よる電位のずれの模式図を Fig. 8 に示す. WEの電位 $E_{\mathrm{WE}}$ と, $\mathrm{RE}$ の電位 $E_{\mathrm{RE}}$ との電位差を測定する場合を示 している. $R_{\mathrm{M}}$ が大きい場合は $\Delta E=E_{\mathrm{WE}}-E_{\mathrm{RE}}$ となる。 し

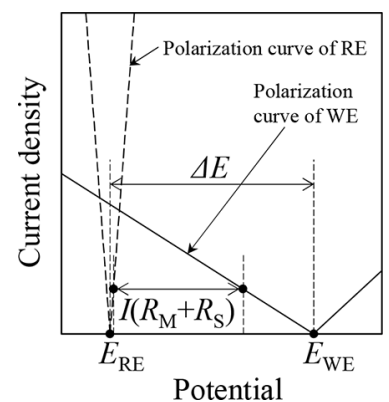

Fig. 8 Pattern diagram for the electrochemical potential difference error by polarization of electrodes. 
かし， $R_{\mathrm{M}}$ が小さいために回路内に閉回路電流 $I$ が流れ た場合の電位差は $I\left(R_{\mathrm{M}}+R_{\mathrm{S}}\right)$ となり, $\Delta E$ よりも小さく なる．さらに，前述したように電位は $R_{\mathrm{M}}$ と $R_{\mathrm{S}}$ に分圧さ れるため, $R_{\mathrm{M}}$ 両端にかかる電位のみが測定されること になる。

分極による䛊差を低減するために，常温での電位測定 であっても，入力インピーダンス $R_{\mathrm{M}}$ が大きい電位差計 (ポテンショメータ，エレトロメータと呼ばれる装置)を 用いることが必要である ${ }^{12)}$. 入力インピーダンスは望大 特性であり，無限大であることが理想的である。しか し，電流 $I$ が流れないと測定できないため，Iを無視し 得るレベルに抑えられる高い入力インピーダンスを有す る電位差計を用いる。たとえば，入力インピーダンスを $10^{12} \sim 10^{14} \Omega^{9)}$ とすることや, $10^{14} \Omega$ 以上 ${ }^{10)}$ とすること, および閉回路電流を $10^{-10} \sim 10^{-15} \mathrm{~A}$ 以下とすること ${ }^{11)}$ など の指標が示されている.

以上述べた分圧，分極による誤差を低減するために は，被測定系に応じた入力インピーダンスを有する電位 差計を選定する必要がある。

\section{2 電極接続方法に起因する誤差}

第 2 の要因は, 電位差計と電極の接続方法に起因する ノイズの重畳である. Fig. 9 に示すように, High を試料 極に，Low を参照極に接続すると，電位差計内を通じて 回路が形成され，測定值にノイズが重畳する可能性があ る $^{19)}$.

電気化学測定に用いられる電位差計には，シングルエ ンド式と差動式の 2 種類がある。シングルエンド電位差 計は, OPアンプを 1 個のみ使用し，Low 側を接地して 使用する。差動式電位差計は OP アンプを 2 個使用し, High，Lowとも GND から絶縁して使用する.

シングルエンドの電位差計における入力インピーダン スのカタログ值は，High-Low 間，および High-GND 間 での值である．Low-GND 間は，カタログなどに記載さ れた入力インピーダンスよりも数桁低い.このため, 被 測定系の低インピーダンス側電極と, 測定系の Low と が容量成分を介して接続された状態になることがある. したがって，测定值に交流ノイズが重畳して，指示值が 安定しない場合がある。被測定系の低インピーダンス側 と GND との間に生じるノイズはコモンモードノイズと 呼ばれる。

差動式電位差計は, High，Low が同インピーダンスで あるため, 上記の課題は考慮不要である。

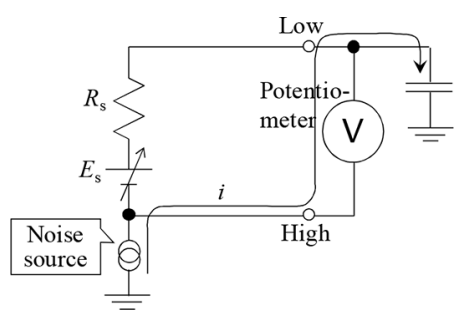

Fig. 9 Effect of common mode noise by wrong connection between the circuit and ground ${ }^{19)}$.

\section{3 接地容器内測定に起因する誤差}

第 3 の要因は, 接地された容器内で測定することに起 因する指示值のずれである。

シングルエンド型電位差計は, Low 端子が接地されて いる．前述したように，安全上の理由からオートクレー ブを接地して使用することが多い.このため接地容器内 でシングルエンド型電位差計を用いて電位を測定する場 合は，意図しない回路が形成され，意図しない電位差が 測定される場合がある. Fig. 10 にシングルエンド型電位 差計による ECP 測定の概要図を示す。エレクトロメータ の High と Low を各電極に直接接続して測定する．金属 電極と外部参照電極とを用いた測定では，通常は金属電 極よりも外部参照電極のほうがアースに対するインピー ダンスが高いため，外部参照電極を High 端子に接続す る. 参照電極の SHE 基準の電位が既知であれば，測定 された電位の符号を正負反転して， REの $\mathrm{SHE}$ 基準の電 位を加算すれば，SHEを基準とした WE の ECP を求め られる。

シングルエンド型電位差計でシングルエンド式接続に より接地容器内で測定する場合の問題点を Fig. 11 に示 す．電位差計の Low が接地されている場合には，GND を経由してオートクレーブと電位差計の Low が電気的 に接続される。この場合, Low-GND 間に電流が流れて 試料極が分極し，誤差を生じることがある。

差動型電位差計は, High 端子, Low 端子ともに接地 されていないため，上述した接地容器内での測定に起因 する誤差は生じない.

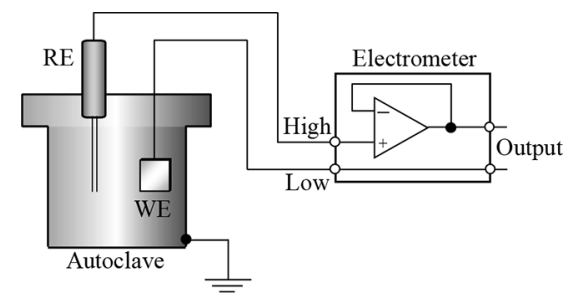

Fig. 10 ECP measurement system by single-ended connection in earthed vessel.

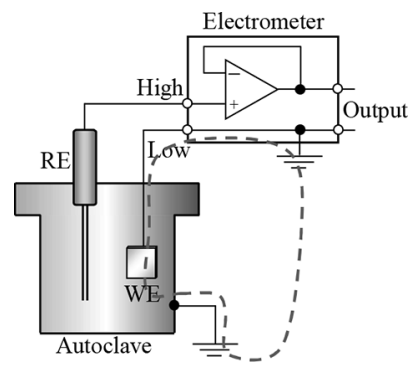

Fig. 11 The issue caused by single-ended connection for ECP measurement in earthed vessel.

\section{4 ケーブル特性に起因する誤差}

第 4 の要因は，ケーブル特性に起因する誤差である. Fig. 12 に，同軸ケーブルの静電容量と絶縁抵抗の模式図 を示す。電位差計で測定する場合，通常は外来ノイズの 重畳を低減するために，BNCケーブルなどの同軸ケー 


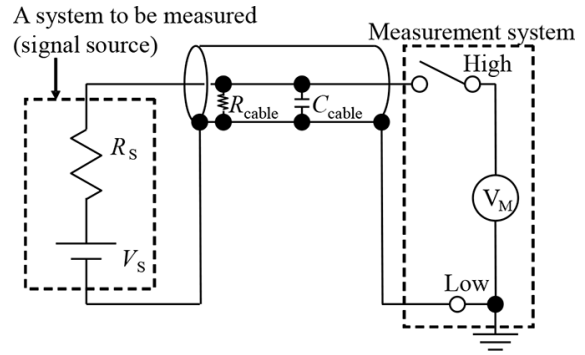

Fig. 12 Cable capacitance and insulation resistance.

ブルが使用される．内部導体に High 端子を接続し，外 部導体には静電遮蔽を兼ねて Low 端子を接続する。同 軸ケーブルの内部導体と外部導体の間には, 絶縁抵抗 $R_{\text {cable }}$ と静電容量 $C_{\text {cable }}$ が存在する. (1)絶縁抵抗 $R_{\text {cable }}$ に起 因して (3) 式で表される指示值 $V_{\mathrm{M}}$ にずれが生じ, (2)静電 容量 $C_{\text {cable }}$ に起因して (4) 式で表される指示值 $V_{\mathrm{M}}$ の遅延 が生じる ${ }^{19)}$.

$$
\begin{aligned}
& V_{\mathrm{M}}=V_{\mathrm{S}}\left(\frac{R_{\text {cable }}}{R_{\text {cable }}+R_{\mathrm{S}}}\right) \\
& V_{\mathrm{M}}=V_{\mathrm{S}}\left(1-e^{-\mathrm{t} / R_{\mathrm{S}} C_{\text {cable }}}\right)
\end{aligned}
$$

$R_{\text {cable }}$ は，ケーブルの絶縁体が劣化した場合や，たとえば 数 $10 \mathrm{~m}$ の長距離にわたってケーブルを敷設した場合に低 くなり，指示值のずれが大きくなる． $R_{\text {cable }}$ の影響は, ソー 又電圧 $V_{\mathrm{S}}$ がソース抵抗 $R_{\mathrm{S}}$ と絶縁抵抗 $R_{\text {cable }}$ に分圧される ことに起因する(式(3)).このため, 入力インピーダンスが $R_{\mathrm{S}}$ より充分大きい電位差計を使用した場合であっても, $R_{\text {cable }}$ と $R_{\mathrm{S}}$ の比に応じて $V_{\mathrm{M}}$ が変化する.

$C_{\text {cable }}$ は，ケーブルが長距離であるほど大きくなり，遅 延時間が大きくなる， $C_{\text {cable }}$ の影響は，指示値の経時的な 変化である. $\mathrm{RC}$ 直列回路では, 式 $(4)$ に示したように $R_{\mathrm{S}}$ と $C_{\text {cable }}$ との積によって, 電圧が安定するまでに時間を 要する.

以上の理由により, 絶縁性が低下した $\left(R_{\text {cable }}\right.$ が低い) 古 いケーブルを使用した場合や，実プラントなどで測定系 と非測定系との距離が長距離である場合は，無視できな い誤差となる場合がある。

\section{5 接地方法に起因する誤差}

第 5 の要因は, 一般に「多重アース(あるいはグラン ド・ループ)」と呼称される接地方法に起因する誤差であ $~^{\left.{ }^{19}\right)}$. 被測定系, 測定系ともにL Low 側を別位置で接地し た場合の, 多重アースによる誤差発生の模式図を Fig. 13 に示す．被測定系と測定系を別々に接地した場合，アー ス線に電位差 $V_{\mathrm{E}}$ が生じることがある．このとき，電位差

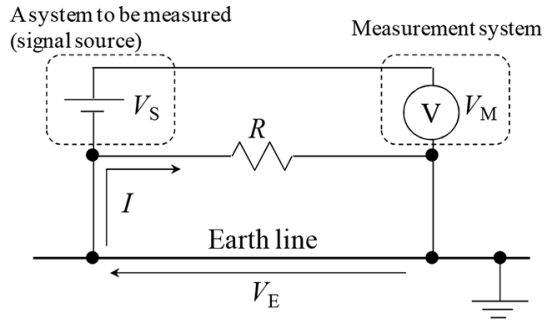

Fig. 13 Pattern diagram of inadequate multipoint grounding ${ }^{19)}$.
計で測定される電位差 $V_{\mathrm{M}}$ は，被測定系のソース電圧 $V_{\mathrm{S}}$ に $V_{\mathrm{E}}(=I R)$ が重畳して誤差が生じる.

電位差計のフレームグランドと测定回路の GND が接 続されている場合があり，また，実プラントにおける測 定のように，WE 自体が接地されている場合がある。こ のため, 認識がないままグランドループが形成されるこ とがある。

なお, 差動式電位差計は, High, Low ともアースと絶 縁されているため, 上記の課題は考慮不要である.

\section{4. 検 討 結 果}

\section{1 被測定系の抵抗に起因する誤差低減}

高温高圧純水中 ECP 測定に特有の課題である課題 1 について，その影響による誤差の大きさを算定した。さ らに，前述した高感度測定ハンドブックに記載された事 項を高温純水中 ECP 測定に当てはめることで，測定誤 差を低減するための対策を検討した。

まず，使用する電位差計の入力インピーダンスについ て述べる. 式(2)-(4)で表される $V_{\mathrm{M}}$ を， $E_{\mathrm{S}}$ に近づけるた めには, 式(5)を満たす電位差計を選定する必要がある.

$$
R_{\mathrm{M}} \gg R_{\mathrm{S}}
$$

課題 1 による誤差の大きさを認識するために, Fig. 7 に示した等価回路を想定した場合の測定誤差 $\delta_{\mathrm{err}}$ を，式 (6)により計算した結果を Fig. 14 に示す.

$$
\delta_{\text {err }}=\left(1-\frac{V_{\mathrm{M}}}{E_{\mathrm{S}}}\right) \times 100=\left(1-\frac{R_{\mathrm{M}}}{R_{\mathrm{S}}+R_{\mathrm{M}}}\right) \times 100
$$

入力インピーダンス $R_{\mathrm{M}}$ がソース抵抗 $R_{\mathrm{S}}$ と等しいと き, 課題 1 に起因する䛊差が $50 \%$ となり， $R_{\mathrm{M}}$ が $R_{\mathrm{S}}$ に比 べて大きくなるほど誤差が減少する，BWRを対象とし た ECP 測定における最大電位差は $1 \mathrm{~V}$ 程度 $\left(\mathrm{Pt}^{24)-25)}\right.$ と固 体電解質型 $\mathrm{Fe} / \mathrm{Fe}_{3} \mathrm{O}_{4}$ センサ ${ }^{26)}$ の電位差)である。した がって，分圧による誤差をたとえば $0.01 \mathrm{~V}$ 以下とするた めには，誤差を $1 \%$ 以下とする必要がある. Fig. 14 の結 果より，誤差を $1 \%$ 以下とするためには， $R_{\mathrm{S}}$ の 100 倍以 上の $R_{\mathrm{M}}$ を有する電位差計を選定する必要がある。

$R_{\mathrm{S}}$ は，前述したように，被測定系に含まれる液抵抗， 電荷移動抵抗, 参照電極の膜抵抗などを含む全抵抗值で ある。ここで一例として，BWR 温度模擬水中 ECP 測定 で広く用いられる, 圧力平衡型 $\mathrm{Ag} / \mathrm{AgCl}$ 外部参照電 極 ${ }^{21)-23)}$ を使用して，高温純水中で ECP を測定する場合

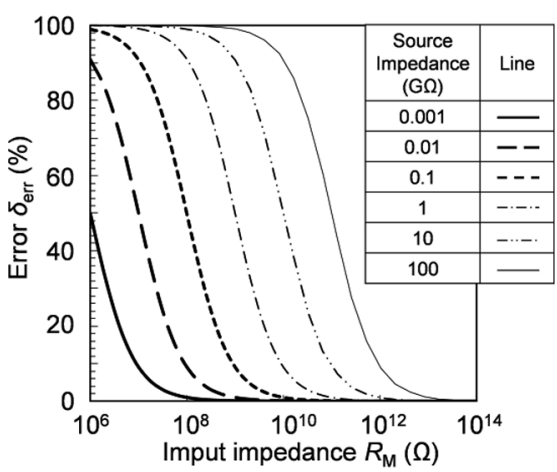

Fig. 14 Calculation results of potential measurement error from source resistance and input impedance. 
の, 液絡管内の液抵抗を算出し, 液絡管内の液抵抗に起 因する誤差を算出した. 水の密度と解離定数 ${ }^{27)}$ から式 （7）を用いて，水の抵抗率 $\rho$ を計算した結果を Fig. 15 に 示す.

$$
\rho^{-1}=\left(\left[\mathrm{H}^{+}\right] \lambda_{\mathrm{H}^{+}}+\left[\mathrm{OH}^{-}\right] \lambda_{\mathrm{OH}^{-}}\right) \cdot P_{\mathrm{W}}
$$

ここで, $\left[\mathrm{H}^{+}\right]$: 水素イオン濃度, $\left[\mathrm{OH}^{-}\right]$: 水酸基濃 度, $P_{\mathrm{W}}$ : 水の密度, $\lambda_{\mathrm{H}^{+}}: \mathrm{H}^{+}$のモル導電率 ${ }^{28)}, \lambda_{\mathrm{OH}^{-}}$: $\mathrm{OH}^{-}$のモル導電率 ${ }^{28)}$ である。

室温における水の電気抵抗率は $18.2 \mathrm{M} \Omega \cdot \mathrm{cm}$ である が, $500 \mathrm{~K}$ 程度までは解離が進み, 電気抵抗率は低下す る ${ }^{27)}$. BWR 炉内温度である 553〜 $561 \mathrm{~K}$ における電気抵 抗率は, 室温の $1 / 20$ 程度に低下し, 約 $1 \mathrm{M} \Omega \cdot \mathrm{cm}$ と なる。

$\mathrm{Ag} / \mathrm{AgCl}$ 型外部参照電極を使用して，液絡管内に一 様に等温の高温純水が満たされているものと仮定し, 誤 差評価を行った。評価する液絡管の寸法は，一例とし て, 筆者らが使用している液絡管 (内径 $2 \mathrm{~mm}$ ) のうち最 も長尺のもの (長さ $50 \mathrm{~cm})$ を想定した.

液絡管内の液抵抗を式(7), 式(8)を用いて計算した結果, $R_{\mathrm{S}}=740 \mathrm{M} \Omega$ と評価された. さらに, 式(6)により $553 \mathrm{~K} に$ おける測定誤差 $\delta$ err を計算した結果, $R_{\mathrm{M}} \geqq 1 \mathrm{~T} \Omega$ とするこ とによって， $\delta_{\mathrm{err}}<0.1 \%$ とできることが分かった(Fig. 16). ここで, $A$ : 伝導体の面積, $L$ : 伝導体の長さである.

$$
R=\rho \frac{L}{A}
$$

以上の検討から，本検討で仮定した高温純水中 ECP 測定においては， $R_{\mathrm{M}}>1 \mathrm{~T} \Omega$ なる入力インピーダンスを

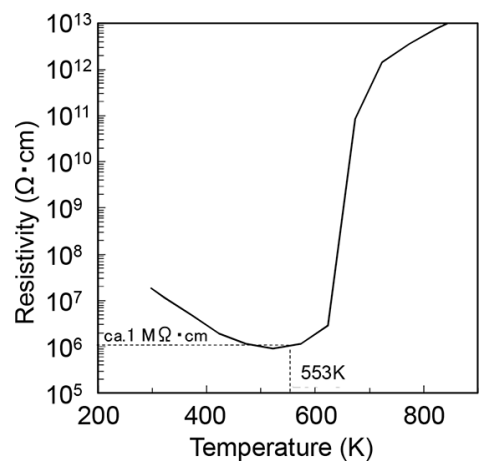

Fig. 15 Relationship of resistance and temperature for high purity water.

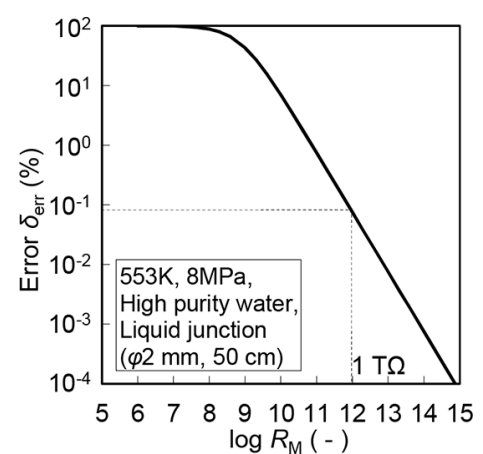

Fig. 16 Calculation results of measurement error by solution resistance in the liquid junction of an external reference electrode.
持つ電位差計を用いることで， $R_{\mathrm{S}}$ に起因する測定誤差を $0.1 \%$ 以下できることが分かった。 なお本結果は一例と して計算した結果であって，液絡管の長さなど，実際に 使用する試験系に応じて評価・選定する必要がある。

\section{2 電極接続方法に起因する誤差低減}

電位差計は, 2 点間の電位差を測定する機器であり, High 端子と Low 端子の 2 端子を備えている.この High / Low は，接続先である被測定系のインピーダンスの高低を 示している. 被測定系のうち, 接地レベル $(\mathrm{GND})$ から見て 高抵抗の側に High 端子を接続する必要がある.

コモンモードノイズは, Fig. 17 に示す適切な High / Low 端子の接続方法では, 電位差計の Low 側と GND 間 に存在する容量成分を通じて外部に流れる。よって，ケー ブルや端子の接続部が十分に低抵抗に保たれていれば, 測定值にノイズが重畳することはない。したがって，被測 定系を構成する電極の対 GND インピーダンスを調べ，高 インピーダンス側の電極に High 端子を接続することで回 避できる，たとえば金属電極と，圧力平衡型外部参照電 極を使用する場合は，金属電極を Lowに，圧力平衡型外 部参照電極を High に接続する.

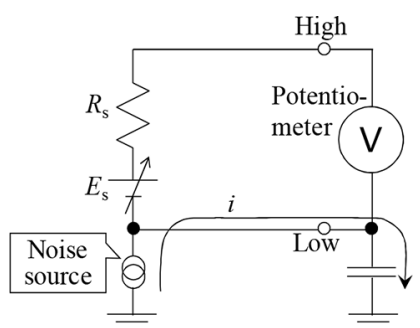

Fig. 17 Appropriate connection concerned about common noise via a ground path ${ }^{19)}$.

\section{3 接地容器内での測定に起因する誤差低減}

シングルエンド型電位差計を使用する場合は, 電極と の接続方法に注意する必要がある. 接地容器内で電位を 測定する際の電位差計と電極との接続方法は, 差動型電 位差計では一種のみであるのに対し，シングルエンド型 電位差計では，シングルエンド式接続と疑似差動式接続 がある。

測定系の Low-GND 間を電気的に絶縁するか，または オートクレーブを非接地とすることにより，この課題は 解消される.

Low-GND 間を電気的に絶縁する方法として, Fig. 18

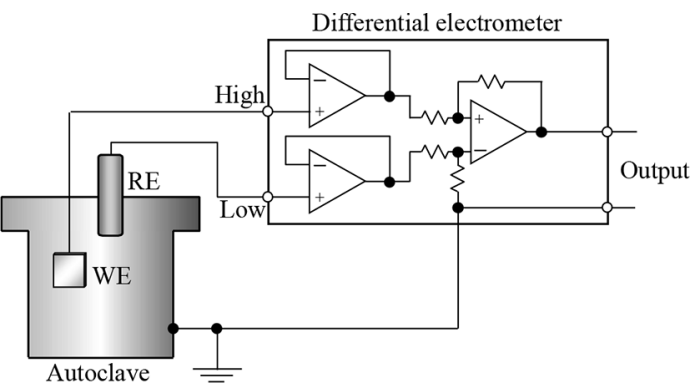

Fig. 18 ECP measurement system by differential electrometer. 
に示した差動型の電位差計を使用する方法がある．差動 式は OPアンプを 2 台使用しており, High / Low 端子 双方の対 GND 絶縁抵抗が高いため課題 3 は生じない.

シングルエンド型の電位差計であっても，疑似差動式 接続とすることで課題 3 を回避できる. Fig. 19 に疑似差 動式入力による ECP 測定の概要図を示す。電気計測用 のエレクトロメータは通常シングルエンド型電位差計で あり，Low 側には OP アンプが使用されていない。この ため Low 端子は, High 端子に比べて対 GND 絶縁抵抗 が数桁低い。一方，被測定系の電極は，純水系の場合は 双方が高インピーダンスである。したがって，双方を OPアンプ側に接続するために, Low 端子を常に接地し ておき, High 端子はスキャナを用いて試料極と参照極 とを切り替える。この構成を用いることで，疑似的に差 動入力型電位差計による測定を実現できる，特に実プラ ントのように，接地された構造材料や配管の複数位置で の ECP を測定する場合は, 接地された構造材料を基準と して参照電極の電位を測定するため, シングルエンド型 電位差計を疑似差動式接続で使用する構成が適している.

シングルエンド接続と疑似差動接続との比較を Table3 に示す．指示值が安定で課題 3 の影響を無視できるた め, 誤差低減の点からは疑似差動式のほうが優れてい る.また，スキャナを用いることで，1台の電位差計で 多点測定ができる利点がある。しかし，製品によっては スキャナ OFF 時に High-Low 間が接続されるモデルもあ る. 複数材料からなる複数の試料を測定する場合, 複数 試料が接続されることによるガルバニック腐食が生じる 可能性がある。回路構成を確認し, ジャンパを切断する などして, 非測定時に試料を測定回路から切り離す必要 がある。

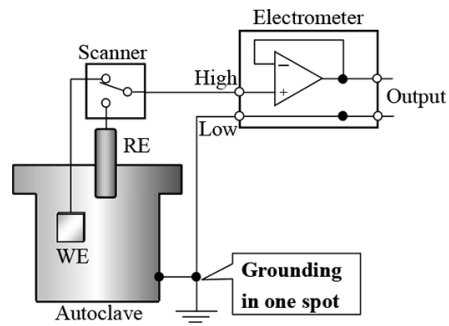

Fig. 19 ECP measurement system quasi-differential connection by using scanner.

Table 3 Comparison between the single-ended connection and the pseudo differential connection.

\begin{tabular}{|c|c|c|}
\hline & (A)Single-ended connection & $\begin{array}{l}\text { (B)Pseudo differential } \\
\text { connection }\end{array}$ \\
\hline Merit & $\begin{array}{l}\text { (1)Simple setup. } \\
\text { (2)Easy to convert to SHE scale } \\
\text { potential. }\end{array}$ & $\begin{array}{l}\text { (1)Multipoint measurement is } \\
\text { feasible by an electrometer. } \\
\text { (2)Pt or Zr can be use as quasi -RE } \\
\text { to verify RE potential during } \\
\text { measurement. } \\
\text { (3)Indicating potential can be } \\
\text { stabilized because Low terminal } \\
\text { can connect to ground. } \\
\text { (4)Potential drift caused by } \\
\text { measurement in grounded vessel } \\
\text { (issue \#3) can be avoided. }\end{array}$ \\
\hline Demerit & $\begin{array}{l}\text { (1)One electrometer can } \\
\text { measure only one electrode. } \\
\text { (3)Potential is unstable because } \\
\text { low terminal have to also } \\
\text { isolate from ground. } \\
\text { (3)Issue \#3 is emerged because } \\
\text { the impedance between the } \\
\text { low terminal versus ground is } \\
\text { low. }\end{array}$ & $\begin{array}{l}\text { (1) There are a lot of contact points. } \\
\text { Lifetime of the contact points } \\
\text { have need to be considered. } \\
\text { (2)Controller is needed to control } \\
\text { switches. Then, the } \\
\text { measurement system is to be } \\
\text { complex. } \\
\text { (3)Delay is occurred due to } \\
\text { switching multiple electrodes. }\end{array}$ \\
\hline
\end{tabular}

\section{4 ケーブル特性に起因する誤差低減}

次に, 課題 4 のケーブル特性に起因する誤差による影 響の大きさを評価し，ならびに対策としてのガードドラ イブ適用の効果を検討した。

Fig. 11 に示したように，BNC 同軸ケーブルの内部導体 と外部導体の間は, 絶縁抵抗 $R_{\text {cable }}$ と静電容量 $C_{\text {cable }}$ を介 して電気的に接続されている。 このため, 式(3), 式(4) で示した 2 種の誤差が生じる. その影響を排するために,

Fig. 20 に示すように OPアンプの出力電圧をケーブルの 外部導体に印加する，ガードドライブ(またはシールドド ライブ，アクティブガードシールド) と呼ばれる手法があ る ${ }^{19)}$ 。 ガードドライブを適用することで, 内部導体と外 部導体との電位差がなくなる。これにより $R_{\text {cable, および }}$ $C_{\text {cable }}$ の両端が同電位となるため, 電流を流す駆動力がな くなり, 内部導体と外部導体との間での電気回路の形成 を妨げることができる．よって， $R_{\text {cable, }}, C_{\text {cable }}$ に起因する 2 種の誤差 (式 (3), 式(4)) を低減できる。 ガード係数 $\mathrm{A}_{\text {guard }}$ (通常 $10^{4} \sim 10^{19)}$ ) に応じて, $R_{\text {cable }}$ による指示值のず れを低減する効果 $($ 式 $(9))$ と, $C_{\text {cable }}$ による指示值遅延時 間を短縮する効果 $($ 式 (10))が得られる.

$$
\begin{aligned}
& V_{\mathrm{M}}=V_{\mathrm{S}}\left(\frac{\mathrm{A}_{\text {guard }} R_{\text {cable }}}{\mathrm{A}_{\text {guard }} R_{\text {cable }}+R_{\mathrm{S}}}\right) \\
& V_{\mathrm{M}}=V_{\mathrm{S}}\left(1-e^{-t \mathrm{Aguard} / R_{\mathrm{S}} C_{\text {cable }}}\right)
\end{aligned}
$$

ガードドライブ適用による誤差の低減効果を確認するた め, $R_{\text {cable }}$ による指示值のずれを式(3), 式(9)で求め, ガー ドドライブあり/なしで比較した. $R_{\text {cable }}$ を 1 ～ $1000 \mathrm{M} \Omega$ と し， $V_{\mathrm{S}}=1 \mathrm{~V}$ を入力した場合の $V_{\mathrm{M}}$ を計算した。 $R_{\text {cable }}$ は, ケーブルが長いほど小さくなる，絶縁体にポリエチレンを 使用した高品質の同軸ケーブルの $R_{\text {cable }}$ は, $1 \mathrm{~m}$ あたり約 $0.31 \mathrm{~T} \Omega$ である ${ }^{19)}$. ケーブル長は, ECP センサと電位差 計の設置位置や，プラントのレイアウトごとに異なる が，実プラントを想定して仮定した．BWRの原子炉建 屋の幅は, ABWR が最大で, $57 \mathrm{~m}$ である ${ }^{29)}$. 原子炉格 納容器 $(\mathrm{PCV})$ 内の原子炉近傍に ECP センサを設置し, $\mathrm{PCV}$ 外の建屋内に計測器を設置して測定することを考え る. ECP センサと電位差計の直線距離を建屋全幅の $1 / 2$ と仮定し, さらに, ケーブルの敷設経路の全長を直線距 離の 2〜3 倍と仮定すれば, 全長 60９0 $\mathrm{m}$ となる. そこ でケーブル長を $90 \mathrm{~m}$ と仮定し, 式(8)により同軸ケーブ ルの $R_{\text {cable }}$ を求めると, $R_{\text {cable }}=3.4 \mathrm{G} \Omega$ となる。ここで は,さらに絶縁が劣化して $R_{\text {cable }}=10 \mathrm{M} \Omega$ 程度にまで低 下し, かつ高温純水中 ECP 测定の最大ソース抵抗とし て, 4.1 で算出した $R_{\mathrm{S}}=740 \mathrm{M} \Omega \doteqdot 1 \mathrm{G} \Omega$ の系を想定し た。

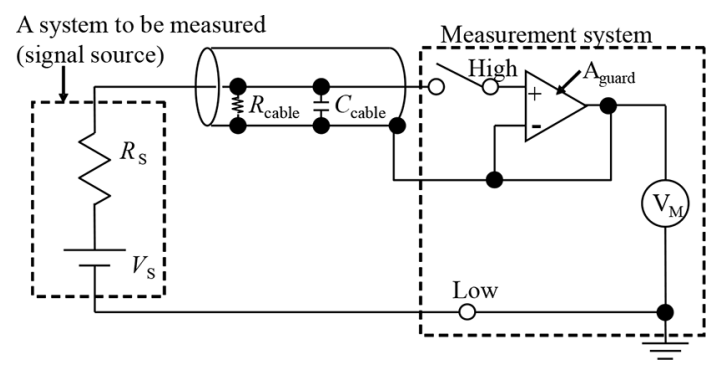

Fig. 20 Framework diagram of a guard drive. 
$R_{\text {cable }}$ に起因する誤差へのガードドライブの効果の計算 結果を Fig. 21 に示す．点線がガードドライブなし，実 線が $A_{\text {guard }}=10^{4}$ のガードドライブありの場合である. ソース抵抗 $R_{\mathrm{S}}$ が高くなるほど $V_{\mathrm{M}}$ と $V_{\mathrm{S}}$ との差違が大き くなることが分かる．また，同じ $R_{\mathrm{S}}$ では $R_{\text {cable }}$ が小さい 場合に $V_{\mathrm{M}}$ と $V_{\mathrm{S}}$ との差違が大きくなる. 一例として, $R_{\text {cable }}=10 \mathrm{M} \Omega, R_{\mathrm{S}}=1 \mathrm{G} \Omega$ の系のとき，ガードドライブな しでは，分圧により $V_{\mathrm{S}}=1 \mathrm{~V}$ の大半が $R_{\mathrm{S}}$ にかかるため 指示值 $V_{\mathrm{M}}$ は約 $0.01 \mathrm{~V}$ (誤差 $99 \%$ ) となる. 一方, ガード ドライブを使用した場合は $0.99 \mathrm{~V}$ を指示し，誤差を $1 \%$ (0.01V)に低減できる。

ただし，ケーブル長が 1 ～ $2 \mathrm{~m}$ 程度である実験室系の 場合，ケーブルや端子の絶縁性が健全であれば，誤差は $1 \%$ 以下となり， $R_{\text {cable }}$ に起因する誤差は無視できる．し たがって，ガードドライブは不可欠ではない．測定対象 回路の $R_{\text {cable }}$ を把握した上で，ガードドライブ採用要否 を判定する必要がある。

静電容量 $C_{\text {cable }}$ による指示值遅延時間を式 (4), 式 (10) で求め, ガードドライブあり／なしで比較した結果を Fig. 22 に示す. 沉用同軸ケーブルの代表的な $C_{\text {cable }}$ とし て $C_{\text {cable }}=85 \mathrm{nF} \cdot \mathrm{km}^{-1}$ とおき, ケーブル長は先の仮定 より $90 \mathrm{~m}$ と仮定した。ガードドライブの適用により, 時定数が短縮されるため, ms オーダーで真值を指示す るようになる．先に計算した液絡管内の抵抗は $740 \mathrm{M} \Omega$ であった。この場合, ガードなしでは最長で約 $50 \mathrm{~s}$ を要 すると評価される，ECPの測定は，ソース電圧の急峻な 変化を捉える必要のない分単位の測定である。このた め, 常に電極を接続したままの方法である場合は問題な い. しかし, 疑似差動式接続で, 複数の電極をスキャナ

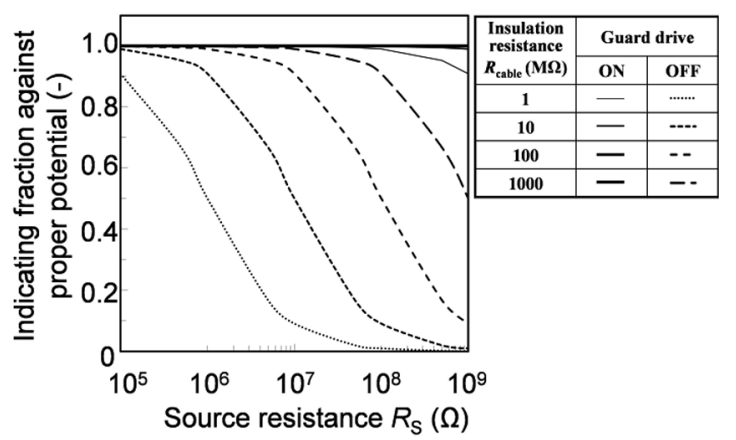

Fig. 21 The effect of the guard drive on measurement error which arise from by $R_{\text {cable. }}$.

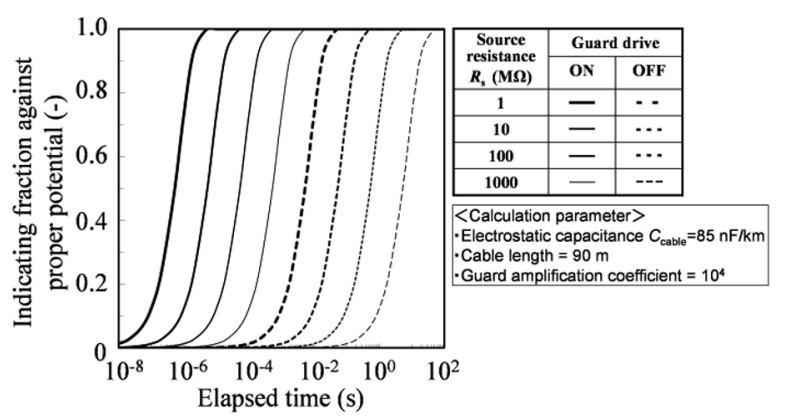

Fig. 22 The effect of the guard drive on indication delaying which arise from by $C_{\text {cable. }}$.
で切り替えて測定する場合には，ガードドライブが有効 であることが分かった。

ただし，ケーブル長が 1 2 m である実験室系の場合， ガードなしでも遅延時間は約 $1 \mathrm{~s}$ 程度であり, 適切な積 分時間を設定することで， $C_{\text {cable }}$ に起因する指示值遅延は 無視でき得る。したがってガードドライブは不可欠では ない. 測定対象回路の $C_{\text {cable }}$ を把握した上で，ガードド ライブ採用要否を判定する必要がある.

なお，プリアンプ出力を装備している電位差計では, ガードとして使用できる。ただし，測定值に応じた電圧 が印可されるため, レンジの設定には注意する必要があ る.

\section{5 接地方法に起因する誤差低減}

適切な接地方法の模式図を Fig. 23 に示す. 多重アー ス形成を回避するために，一点接地とする必要がある. 測定系・非測定系全体を，低インピーダンス位置の 1 箇 所のみで，低抵抗の太い短い線を用いて接地する．この とき，スター型接続とする．たとえば接地容器内で電位 を測定する場合は, アースを容器に接続した接続点から 電位差計などの各機器のアースに接続する。これにより 循環電流が発生せず，予期しない電圧降下を防止でき る.このとき, 各機器のリアパネルのアース端子とコン セントのアース端子が電気的に接続されているモデルの 場合は, どちらか一方のみを接続し, 他方は開放してお く必要がある.

実プラントの配管などの電位測定において，電位測定 用の電極を新たに装荷せず，参照電極のみを装荷して配 管の ECP を直接測定する場合は, 接地された実プラン 卜材料が測定対象となる。そのような場合は, Fig. 5 に 示したように, 機器のアースを実プラント材料から取る 回路構成とすることが必要となる。

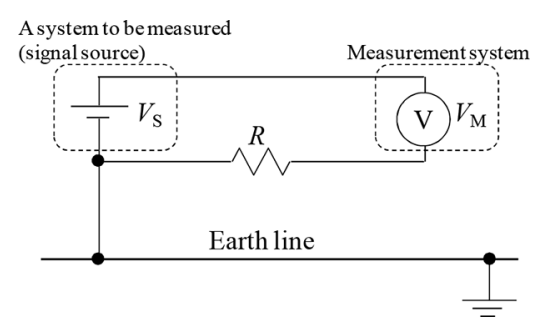

Fig. 23 Pattern diagram of one point grounding ${ }^{19)}$.

6. 結 言

SCC 進展速度評価の一指標として用いる ECP の測定 誤差を低減するために，ECP 測定系に対して一般電気回 路向けの高感度測定法を適用した．接地金属容器内にお ける高温純水中 ECP 測定を対象として，主に電気的観 点から，課題とその対策を検討したＥＥP 測定の誤差低 減のために有効な対策を以下に示す。

・機器選定の観点では，高い液抵抗に起因する分圧によ る誤差を低減するために, 入力インピーダンス $1 \mathrm{~T} \Omega$ 以上の電位差計を使用することが必要である.

・接地容器内での測定に起因する誤差を低減する観点で 
は,アースラインを通じたコモンモードノイズ低減の ため, 差動型の電位差計を用いるか, または, 被測定 系のインピーダンスの高い側を電位差計の High 端子 に，低いほうをLow 端子に接続する必要がある。

・シングルエンド型電位差計を用いた場合でも, High 端子側にスキャナを接続して疑似差動式接続とするこ とで, 各電極を GND から絶縁できるため, 接地容器 内での測定に起因する誤差を低減できる.

・ケーブルが長距離にわたる場合や，その絶縁性が低い 場合，ガードドライブを使用することにより，ケーブ ルの絶縁抵抗と静電容量の影響を無視できるため, 誤 差低減と指示值安定時間短縮に有効である.

・接地方法の観点では, 測定系全体を一点で接地して多 重アースを回避することで循環電流を回避できるた め, グランドループによる誤差を低減できる。

\section{参 考 文 献}

1) S. Suzuki, Zairyo-to-Kankyo, 48, p.753 (1999).

2) R. L. Cowan, M. E. Indig, J. N. Kass, R. J. Raw and L. L. Sundberg, Proc. 4th Water Chemistry of Nuclear Reactor Systems, London, BNES, p.29 (1986).

3) Codes for Nuclear Power Generation Facilities - Rules on Fitness-for-Service for Nuclear Power Plants, JSME, JSME S NA1-2012(2012).

4) Y. Wada, A. Watanabe, M. Tachibana, N. Uetake, S. Uchida and K. Ishigure, J. Nucl. Sci. Technol., 37, p.901 (2000).

5) M.E. Indig and A.R. Mcllree, Corrosion, 35, p.288 (1979).

6) N. Ichikawa, Y. Hemmi and J. Takagi, Proc. 6th Water Chemistry of Nuclear Reactor Systems, Bournemouth, BNES, p.127 (1992).

7) J. Takagi, N. Ichikawa and Y. Hemmi, Proc. Water Chemistry in Nuclear Power Plants, Tokyo, JAIF, p.517 (1988).

8) M. Tachibana, K. Ishida, Y. Wada, M. Aizawa and M. Fuse, J. Nucl. Sci. and Technol., 46 [2] p.132 (2009).

9) E.E. Stansbury and R.A. Buckanan, Fundamentals of Electrochemical Corrosion, ASM International (2000).

10) D. T. Sawyer, A. Sobkowiak and J. L. Roberts Jr., Electrochemistry for chemists, 2nd Edition, Maruzen (2003).

11) A. Fujishima, M. Aizawa and T. Inoue, Electrochemical measurement method, Gihodo-syuppan (1984).

12) Q\&A on Metallic Corrosion Electrochemistry (Jpn.), JSCE (2002).
13) H. Nakauchi, Boshoku-Gijutsu (presently Zairyo-toKankyo), 22, p.415(1973).

14) Y. Yamamoto, C. Kato, T. Sato, J. Nakano, H. Ugachi, T Tsukada, Y. Kaji, S. Tsujikawa, S, Hattori, T, Yoshii, T. Kudo, R. Nemoto and M. Akashi, JAEA-Review 2012-007 (2012).

15) Standard Guide for Electrode Potential Measurement, ASTM G215-16, American Society for Testing and Materials (2016).

16) Standard Practice for Conventions Applicable to Electrochemical Measurements in Corrosion Testing, ASTM G3-14, American Society for Testing and Materials (2014).

17) Conventions applicable to electrochemical measurements in corrosion testing, ISO 17475 : 2005, International Organization for Standardization (2005).

18) Boiler feed water and boiler water - Testing methods, JIS B 8224:2016 appendix D, Japan Standards Association (2016).

19) Low level measurements handbook, 6th Edition, KEITHLEY (2004).

20) K. Ishida, I. Tamura, S. Ogawa, H. Abe, T. Mishiro, H. Morioka, T. Kawakami, N. Ohta, N. Usui, M. Yamazaki, M. Fuse, M. Tachibana and Y. Wada, Proc. Int. Conf. on Water Chem. of Nuclear Reactor Systems, Berlin, Paper No. L043 (2008).

21) D.D. Macdonald, A.C. Scott and P. Wentrcek, J. Electrochem. Soc. 126, p.1618(1979).

22) T. Sunaba, T. Fujii and K. Tachibana, Zairyo-to-Kankyo, 56, p.70 (2007).

23) K. Tachibana, Corrosion Engineering, 34, p.308(1985).

24) Y. Wada, K. Ishida, M. Tachibana, M. Aizawa and M. Fuse, J. Nucl. Sci. and Technol., 44, p.1448 (2007).

25) Y. J. Kim, Corrosion, 61, p.889 (2005).

26) T. Tsukada, Y. Miwa, H. Ugachi, Y. Matsui, Y. Itabashi, N. Nagata and K. Douzaki, Proc. Int'l Conference on Water Chemistry of Nuclear Reactor Systems, California, p.2200. (2004).

27) JSME Steam Tables based on IAPWS-IF97, JSME (1999).

28) A.L.Horvath, Handbook of Aqueous Electrolyte Solutions, Ellis Horwood ltd. (1985).

29) Overview of Light Water Nuclear Power Stations (Revised edition), Nuclear Safety Research Association Ed., p.348 (1992).
(Manuscript received April 7, 2017; in final form June 12, 2017)

BWR 炉水温度条件の純水中における ECP 測定法に，一般電気回路を対象とした高感度測定法を適用 し，測定に関わる課題を明確化し，その対策を述べた. キーワード＼cjkstart腐食電位, 沸騰水型原子炉, 高温水, 純水 